\title{
Mapping the Arts Anak Nagari: Cultural Tourism Strategy in Solok District, West Sumatra
}

\author{
Admiral $^{1} \quad$ Darmansyah $^{1} \quad$ Febri Yulika $^{2} \quad$ AAA. Citrawati ${ }^{3}$ \\ 1.Karawitan Arts, Faculty Of Art Perform, Art Institute of Indonesia Padang Panjang \\ 2.Antropologi Culture, Art Institute of Indonesia Padang Panjang \\ 3.Dance Arts, Faculty Of Art Perform, Art Institute of Indonesia Padang Panjang
}

\begin{abstract}
West Sumatra is one of the provinces that have potential tourism opportunities in attracting domestic and foreign tourists. Solok Regency as one of the administrative regions in West Sumatra seeks to seize this opportunity by exploring all the tourism potential in the area. The beauty of the landscape and the wealth of natural resources in Solok Regency are also supported by abundant cultural property in the form of art. This abundant cultural property can be used as a potential tourist attraction for visiting the Regency of Solok. The local government through the Department of Tourism and Culture captures this market share to be explored in order to support the tourism program in Solok Regency. Concretely, Solok Regency has launched a number of Nagari (sub-district level) in the area as "Culture Tourism" or Kampung Budaya.To realize cultural tourism in Solok Regency, it is deemed necessary to map art studio or galleries located in Solok Regency as an effort to preserve cultural values and to find out in detail the strength of the region in developing the potential for cultural tourism. Art studio is a place or facility used by a community or group of people to carry out artistic activities such as dancing, painting, crafts and acting. This study will explain in detail and communicative the mapping of art studios and traditional values in Solok Regency so that they can be used as cultural forces to support the implementation of cultural tourism in Solok Regency.
\end{abstract}

Keywords : Children ;, mapping Nagari; Potential; Culture tour;

DOI: $10.7176 / \mathrm{ADS} / 78-03$

Publication date: November 30th 2019

\section{A. PREFACE}

Solok Regency as one of the administrative regions in the province of West Sumatra is trying to capture this opportunity by exploring all the tourism potential in the region. Supported by very beautiful natural potential and abundant natural resources, Solok Regency is trying to change its face to become a Regency tourism destination. Geographically, the location of Solok Regency is between $00^{\circ} 32^{\prime} 14^{\prime}$ and $01^{\circ} 46^{\prime} 45^{\prime \prime S o u t h}$ Latitude and $100^{\circ}$ 25" 00 "and $101^{\circ} 41^{\prime \prime} 41$ "East Longitude. The topography of this region varies greatly between plains, valleys. and hills, with a height of 329 meters - 1,458 meters above sea level. Solok Regency has several lakes that are famous for their natural beauty. Among the lakes, the largest is Lake Singkarak, followed by Twin Lakes (Lake Diateh and Lake Dibawah), and Lake Talang. In addition, Solok Regency also has one volcano, namely Mount Talang. The position of Solok Regency is very strategic because it is crossed by Jalan Lintas Sumatra and directly borders with Padang City as the capital of West Sumatra Province. As the center of rice production in West Sumatra, in 2010 the largest rice field area in Solok Regency was in Gunung Talang district, then followed by Kubung District and Bukit Sundi District. In other Districts, the area of rice fields is still under 3000 hectares. The beauty of the landscape and the wealth of natural resources in Solok Regency are also supported by abundant cultural property in the form of art. This abundant cultural property can be used as a potential tourist attraction for visiting the Regency of Solok. The local government through the Department of Tourism and Culture captures this market share to be explored in order to support the tourism program in Solok Regency. Concretely, the Solok District has launched a number of Nagari (sub-district level) in the area as "Cultural Tourism" or Kampung Budaya such as Nagari Jawi Jawi Gunung Talang District and Nagari Selayo Kubung District. Kampung Budaya "Cultural tourism" is a general description of the culture that is spread in these areas in the form of Art, Customs, and other Diversity that is depicted in the nagari / kampung

To realize cultural tourism in Solok Regency, it is deemed necessary to map art studio or galleries located in Solok Regency as an effort to preserve cultural values and to find out in detail the strength of the region in developing the potential for cultural tourism. The definition of mapping literally according to the big Indonesian dictionary (1987: 859) is the process, way, actions of making maps, photography activities carried out through the air where this activity aims to improve the good imaging results of an area (Yusuf, et. al, 1957: 452). Another definition of mapping is the grouping of groups of regions that are related to several geographical locations of the region which include plateaus, mountains, resources and potential populations that have socio-cultural influences that have special characteristics in the use of appropriate scales. (Soekidjo, 1994: 34).

Meanwhile, an art studio is a place or facility used by a community or group of people to carry out artistic activities such as dancing, painting, crafts and acting. Activities in an art studio are learning activities about art 
that cover the process from learning, creation to production and most of the process is done in the studio (depending on the availability of facilities in the studio). For example if the work produced is in the form of fine arts (sculpture, painting, handicrafts, etc.), then the final process is an exhibition, while the work in the form of performing arts (theater, dance, pantomime, etc.), then the last process is a performance. Art studios are included in non-formal educational institutions. these studios are usually set up privately or individually with learning space and facilities in the studio depending on the capabilities of each studio. There are studios that have very limited facilities but some are complete. In addition, the systems and activities that occur in art studios are very flexible, such as administrative procedures, procurement of certificates, learning processes including learning and evaluation methods, etc. Which follows the policies and rules of each studio so that differences arise between the studios. Due to individually founded, art studios are usually private, and for the equal distribution of educational results they must go through an equalization assessment process by an institution appointed by the Government or Local Government to be equal to the results of formal education.

So the implementation of this research aims to realize cultural resilience in Solok Regency through the mapping of art studios and traditional values in Solok Regency as an effort to preserve cultural values and to find out in detail the strength of the region in developing its cultural tourism potential.

\section{B. Methodology}

1. Research Methodology

The method used in this study is a qualitative method with a descriptive analysis approach. According to Creswell, the qualitative assessment process involves important efforts, such as collecting data, asking questions, and analyzing certain data. Qualitative research methods are used because this research only describes situations / events and is not intended to seek or explain relationships and not test hypotheses or make predictions (Grace, 2001: 24).

In this study the data obtained are in the form of numbers, words and images. Data comes from field notes, field data collection, and other official documents. To analyze data, the authors apply descriptive analysis which aims to describe systematically, factually, and accurately about the facts and characteristics of certain objects. Based on the methodology above, this study will illustrate qualitative mapping in the form of figures about the existence of art studios located in the nagari in Solok District while descriptive mapping will take the form of narratives about the traditional art heritage developed by the studio so that the inherited traditional art can be used as cultural resilience in realizing cultural tourism in Solok Regency.

\section{Data Collection Techniques \\ 2.1 Early Stages}

At this stage the researcher seeks to obtain written sources and oral sources or primary and secondary sources. Oral sources were obtained through interviews with artists, cultural observers and observers of traditional arts (music). While the literature study is carried out by gathering a number of opinions and theories, which can help in analyzing or interpreting the existence of traditional art in Solok Regency. Literature studies will be conducted in a number of libraries, such as: libraries located in several universities in West Sumatra; library in a government office environment; and certain private library collections.

\subsection{Data Collection}

Field data collection is carried out in the form of 'ethics' and 'emics'. The 'ethical' approach is carried out directly in the field, by preparing questions that are in accordance with previously formulated problems. The next approach is 'emic' with the technique of interviewing informants who have the capacity related to the research problem.

In accordance with the development of information technology, field data collection is also carried out by utilizing information technology in the form of long-distance interviews, via cell phones and regular telephones. Because of limited phenomena that can be captured in direct interviews, sound recordings and videos are used. Documenting traditional art is done indoors and outdoors. Individuals and groups are subjected to documentation and recordings.

\subsection{Data Processing and Analysis}

Data collected needs to be identified and classified. Data identification is expected to be qualitative. At this stage, the validity of the data will be considered accurately so that the results of experimental work can be justified. With this also the conclusion can be drawn easily. Data will be presented in tables and diagrams.

\subsection{Report Compilation}

The preparations for this progress report have been carried out from the beginning of the data collection. Written data has been framed and grouped as a whole. The purpose of the preparation is so that the discussion of the 
proposed topic can be synchronized and accounted for in accordance with the proposal, as well as scientific evidence of research that has been done. At this stage all the descriptions that have been submitted are combined with some appropriate theoretical approaches.

\section{RESULTS}

\section{Solok District profile}

Solok Regency as one of the administrative regions in the province of West Sumatra is trying to capture this opportunity by exploring all the tourism potential in the region. Supported by very beautiful natural potential and abundant natural resources, Solok Regency is trying to change its face to become a Regency tourism destination. Geographically, the location of Solok Regency is between $00^{\circ} 32$ ' $14^{\prime}$ ' and $01^{\circ} 46$ ' 45 "South Latitude and $100^{\circ}$ $25^{\prime} 00$ "and $101^{\circ} 41^{\prime \prime} 41$ "East Longitude. The topography of this region varies greatly between plains, valleys. and hills, with a height of 329 meters - 1,458 meters above sea level. Solok Regency has several lakes that are famous for their natural beauty. Among the lakes, the largest is Lake Singkarak, followed by Twin Lakes (Lake Diateh and Lake Dibawah), and Lake Talang. In addition, Solok Regency also has one volcano, namely Mount Talang. The position of Solok Regency is very strategic because it is crossed by Jalan Lintas Sumatra and directly borders with Padang City as the capital of West Sumatra Province. As the center of rice production in West Sumatra, in 2010 the largest rice field area in Solok Regency was in Gunung Talang district, then followed by Kubung District and Bukit Sundi District. In other Districts, the area of rice fields is still under 3000 hectares.

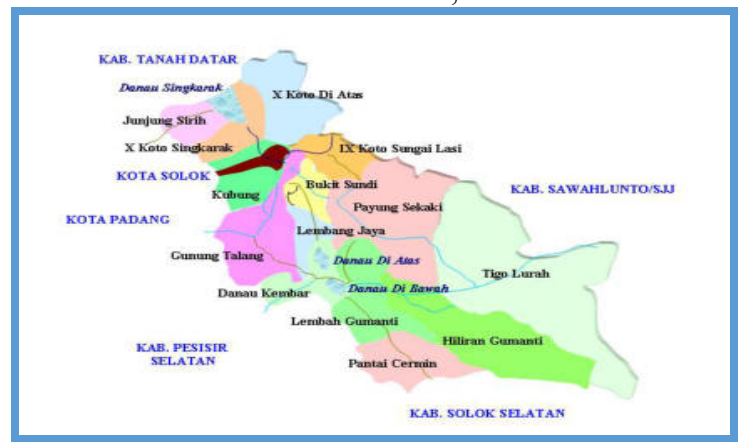

Picture 1 Map of Solok District Administration

Solok Regency consists of 14 subdistricts and 74 Nagari with Aro Likes Capital District, located in District of Mount Talang.

\section{Art Mapping}

In conducting mapping, the first step is to collect art data in Solok Regency.

This data collection process is used to identify traditional arts that are still carried out by the community in Solok Regency. Identification of active Art Traditions is based on the number of art studios that are actively involved in Art Tradition activities in Solok Regency.

There are many traditional Nagari art studios in Solok Regency. Based on data obtained in 2018 there were 298 studios spread across 14 districts that currently have building permits and are legally recognized by the government. This data is based on the Solok District Art Profile in 2018 issued by the Solok Regency Tourism and Culture Office.. 
Table 1 Distribution of Kids Art Nagari in Solok Perkecamatan

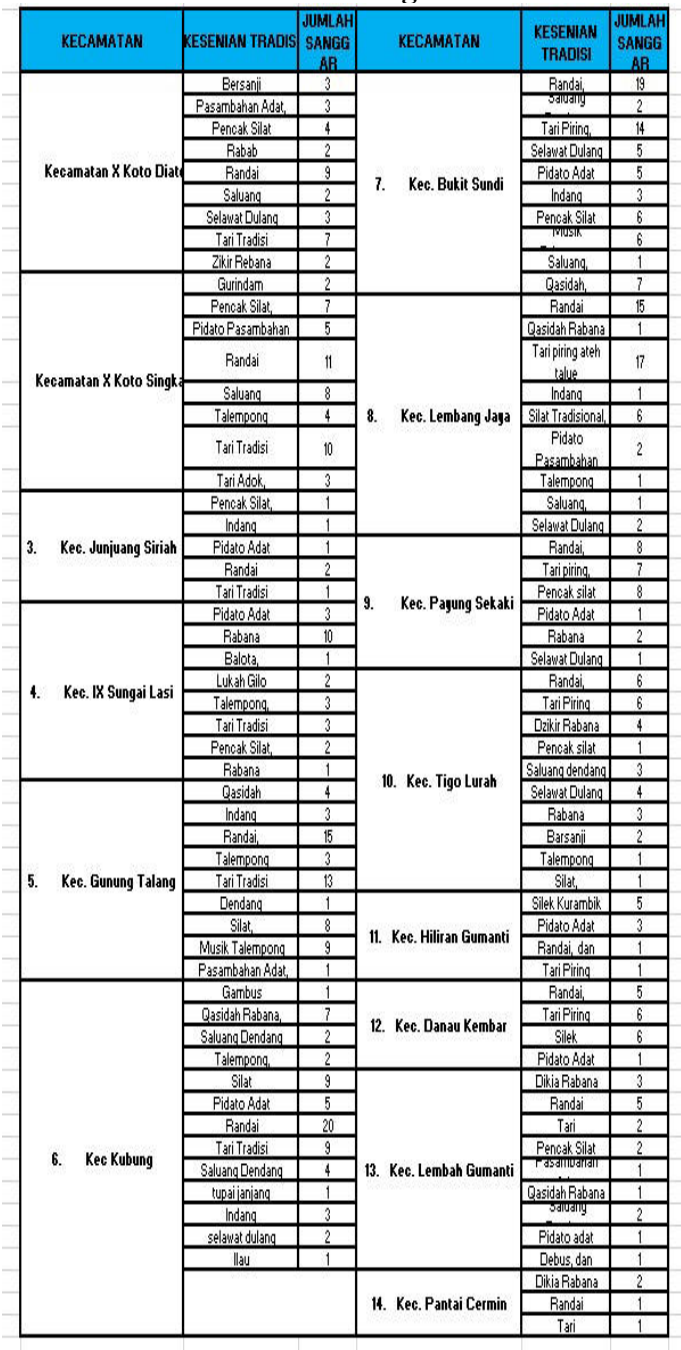

Table 2 Kids Art recapitulation Nagari in Solok

\begin{tabular}{|c|c|c|c|c|c|c|c|c|c|c|c|c|}
\hline $\begin{array}{l}\text { KESENIAN ANAK } \\
\text { NAGARI }\end{array}$ & 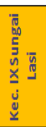 & 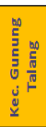 & 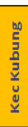 & 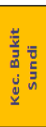 & 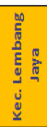 & 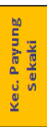 & 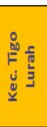 & 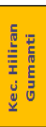 & 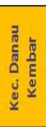 & 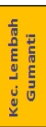 & 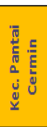 & Jumlah \\
\hline Bersanji & 0 & 0 & 0 & 0 & 0 & 0 & 2 & 0 & 0 & 0 & 0 & 2 \\
\hline Balota & 1 & 0 & 0 & 0 & 0 & 0 & 0 & 0 & 0 & 0 & 0 & 1 \\
\hline Gambus & 0 & 0 & 1 & 0 & 0 & 0 & 0 & 0 & 0 & 0 & 0 & 1 \\
\hline Gurindam & 0 & 0 & 0 & 0 & 0 & 0 & 0 & 0 & 0 & 0 & 0 & 0 \\
\hline Ilau & 2 & 0 & 0 & 0 & 0 & 0 & 3 & 0 & 0 & 1 & 0 & 6 \\
\hline Indang & 0 & 3 & 3 & 3 & 1 & 0 & 0 & 0 & 0 & 0 & 0 & 10 \\
\hline Lukah Gilo & 2 & 0 & 2 & 0 & 0 & 0 & 0 & 0 & 0 & 0 & 0 & 4 \\
\hline $\begin{array}{l}\begin{array}{l}\text { Pasambahanan/Pidato } \\
\text { Adat }\end{array} \\
\text { ald }\end{array}$ & 3 & 1 & 5 & 5 & 2 & 1 & 1 & 3 & 1 & 1 & 0 & 23 \\
\hline Pencak Silat & 2 & 8 & 9 & 6 & 6 & 8 & 2 & 5 & 6 & 2 & 0 & 54 \\
\hline Rabab & 0 & 0 & 0 & 0 & 0 & 0 & 0 & 0 & 0 & 0 & 0 & 0 \\
\hline Rabana / Qasidah & 10 & 4 & 7 & 7 & 1 & 2 & 7 & 0 & 0 & 4 & 2 & 44 \\
\hline Randai & 0 & 15 & 20 & 19 & 15 & 8 & 6 & 1 & 5 & 5 & 1 & 95 \\
\hline Saluang & 0 & 0 & 6 & 3 & 1 & 0 & 3 & 0 & 0 & 2 & 0 & 15 \\
\hline Selawat Dulang & 0 & 0 & 2 & 5 & 2 & 1 & 4 & 0 & 0 & 0 & 0 & 14 \\
\hline Talempong & 3 & 9 & 1 & 6 & 1 & 0 & 1 & 0 & 0 & 0 & 0 & 21 \\
\hline Tari Tradisi & 3 & 13 & 9 & 14 & 17 & 7 & 6 & 1 & 6 & 2 & 1 & 79 \\
\hline \begin{tabular}{|l} 
Tupai Ianjang \\
\end{tabular} & 0 & 0 & 1 & 0 & 0 & 0 & 0 & 0 & 0 & 0 & 0 & 1 \\
\hline Zikir Rebana & 0 & 0 & 0 & 3 & 0 & 4 & 0 & 2 & 0 & 2 & 0 & 11 \\
\hline
\end{tabular}




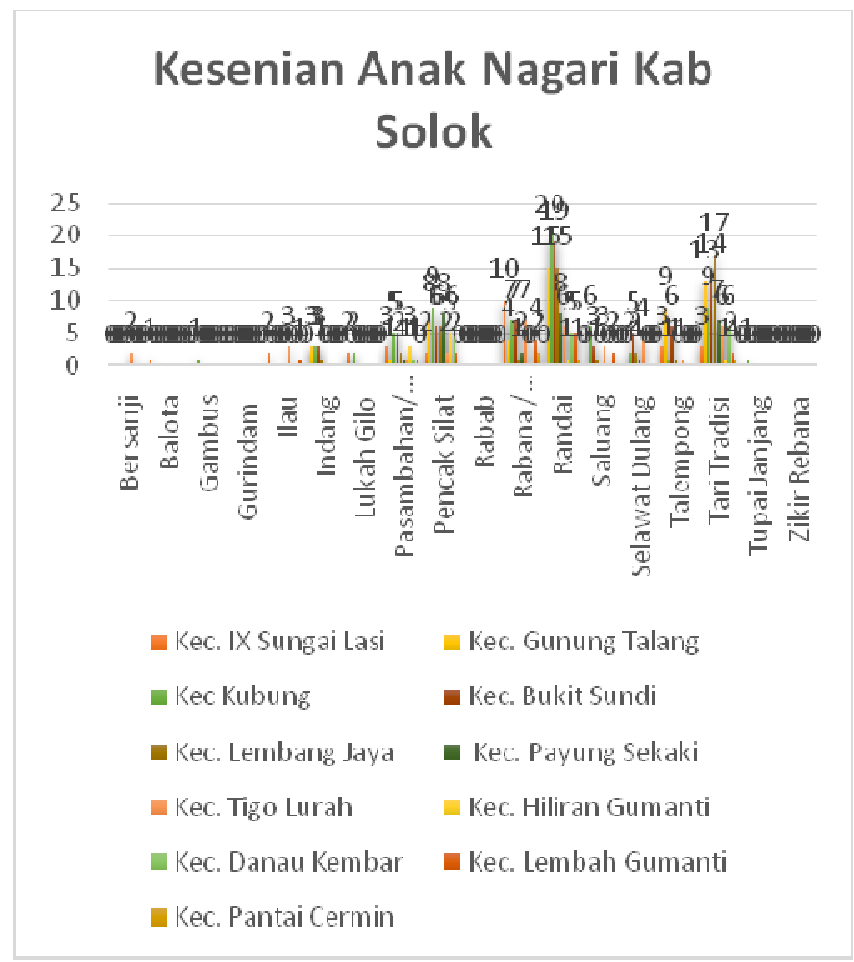

Graph 1 Kids Art Data Nagari in Solok

\section{Cultural Tourism Strategy}

The packaging strategy for local culture, especially cultural tourism in Solok Regency, must be based on a SWOT analysis. SWOT analysis is one method for developing conditions and evaluating problems, projects or business concepts based on internal and external factors (ie Strengths, Weaknesses, Opportunities and Threats), this method is most often used in evaluation methods to find strategies The SWOT analysis consists of four factors:

a. Strength is the quality or condition of being strong, the factors that exist within the organization, especially in tourism, which with existing strengths can be developed to be more resilient in order to survive in the market and can design for further development related to tourism

b. Weakness is the state or condition of lacking strength found in the organization, namely all factors that are unfavorable or detrimental to the development of cultural tourism.

c. Opportunities is a set of circumstances that makes it possible to do something.

d. Threats are conditions that threaten from the outside. This threat can disrupt the organization.

According to Santono (2001) in Anjela (2014) SWOT analysis is a systematic identification of various factors to formulate a strategy that is expected to solve a problem, this analysis is based on logic that can maximize strengths and opportunities, but at the same time can minimize weaknesses and threats. Also according to Sthepen (1999) in Murdani (2014) SWOT analysis is an analysis based on strengths, weaknesses, opportunities, opportunities and threats

Below is a SWOT Analysis of the Embodiment of Cultural Tourism in Solok District Based on the Art Mapping of Anak Nagari that has been carried out: 
Table 4 SWOT Analysis Cultural Tourism, Regency. Solok

\begin{tabular}{|c|c|c|}
\hline $\begin{array}{c}\text { Solok District } \\
\text { embodiment Cultural } \\
\text { Tourism }\end{array}$ & $\begin{array}{ll}\text { strenght / Power } \\
\checkmark & \text { Mapped art potential of Nagari Children } \\
\checkmark & \text { The potential of Nagari Children's Art is } \\
\checkmark & \text { a characteristic of regionalism } \\
\checkmark & \text { Good governance } \\
\checkmark & \text { HR that supports the development of } \\
& \text { Cultural Tourism }\end{array}$ & $\begin{array}{l}\text { Weakness / Weakness } \\
\checkmark \quad \text { Inadequate infrastructure at some } \\
\text { locations cultural tourism } \\
\checkmark \quad \text { Lack of promotion of tourist } \\
\text { destinations }\end{array}$ \\
\hline & $\begin{array}{l}\text { opportunity /chance } \\
\checkmark \quad \text { Cooperation in the development of } \\
\text { cultural tourism between the local } \\
\text { government and the community. } \\
\checkmark \text { Emergence of tourism awareness } \\
\text { groups }\end{array}$ & $\begin{array}{l}\text { Threats / Threat } \\
\checkmark \quad \text { Some cultural tourism } \\
\text { development sites are in } \\
\text { disaster prone areas } \\
\checkmark \quad \text { The same traditional arts as other } \\
\text { regencies. }\end{array}$ \\
\hline
\end{tabular}

After mapping the art, it was found that the traditional children's art of Solok Regency had two categories that could be used as tourism potential. Manifestation of this potential is the formation of "Nagari Wisata Budaya" (Culture Tourism). This is also based on the SWOT Analysis conducted above.

Based on the mapping done above, the conclusion is that Gunung Talang and Kubung are two sub-districts that have the potential of children's traditional arts that can be enjoyed by tourists namely randai and traditional dances. The Solok Regency Government responded quickly by establishing Nagari Jawi Jawi as a Cultural Tourism Village. The Ministry of Tourism of the Republic of Indonesia also mentioned that Nagari Jawi-Jawi Guguk, Gunung Talang Regency, Solok Regency are included in 10 priority villages which will be used as cultural villages for tourism development in Indonesia. Village culture is one implementation for the preservation of the values of tradition, local culture and the art of "Anak Nagari".

\section{REFERENCES}

Yulia Sariwaty (2018); Travel Marketing Communication Strategy Koro Nagari Hilalang; Journal of Integrated Tourism (JPT) Vol 3 No. 1; Universitas Bina Sarana Informatika.

Firdaus Marbun (2017); "Revitalization of Traditional Arts in Solok"; Research Report; Institute for Preservation of Cultural Values BPNB West Sumatra.

Kuswasantyo (2015); Research Report "Mapping the Traditional Arts In Yogyakarta; Yogyakarta State University. 